\title{
Achieving Certainty in Treaties with Indigenous Peoples: Small Steps Towards Adopting Elements of Recognition
}

\author{
John Helis*
}

\section{Introduction}

The Eeyou Marine Region Land Claims Agreement (EMRLCA) with the James Bay Cree of northern Quebec contains a novel approach to achieving certainty in treaties with Indigenous peoples. For the federal government, the certainty of having the rights of an Indigenous nation exhaustively set out in one document is the benefit derived from treaties. Unlike Aboriginal rights, which the government views as ambiguous and hard to define, treaties are negotiated agreements that clearly outline rights. The goal of government when negotiating treaties is therefore to ensure that the Indigenous group can only exercise treaty rights and not their pre-existing Aboriginal rights which are recognized by the common law and the Constitution Act, $1982 .{ }^{1}$

Accordingly, at the insistence of the federal government, treaties contain provisions that seek to effectively neutralize Aboriginal rights to ensure that only treaty rights can be enforced. The longstanding method for obtaining certainty was to extinguish Aboriginal rights outright and replace them with specific rights outlined in the treaty. This provided the federal government with the certainty that pre-existing Aboriginal rights could not be asserted, although it also alienated Indigenous peoples from their traditional rights that are considered sacred and at the core of their identity. Consequently, the call for the recognition and affirmation of Aboriginal rights, rather than their extinguishment, has been made not only by Indigenous peoples, but also by academics and a diverse set of groups ranging from the Royal Commission on Aboriginal Peoples to the United Nations. ${ }^{2}$

This divergence on how to address certainty and the status of pre-existing Aboriginal rights in treaties has resulted in a longstanding debate, and several attempts at devising new models of satisfying the federal government's requirement for certainty without the extinguishment of rights have been made. Unfortunately, as with treaty negotiations overall, the incorporation of Indigenous perspectives has been a painstakingly slow process. The stages in this process include blanket extinguishment of all Aboriginal rights and title, partial extinguishment of Aboriginal title to certain lands, and since the 1998 Nisga'a Final Agreement, new models of achieving certainty that modify Aboriginal rights or which prevent their assertion. The more recent models of achieving certainty represent important milestones in the move away from the traditional approach of extinguishment, although they have also been criticized for being de facto extinguishment by implication if not by express language.

The purpose of this paper is to examine the newest model of achieving certainty found in the EMRLCA. This model, which can be described as the 'partial modified rights approach', seeks to modify Aboriginal rights related to land and 
resources only to the extent required to ensure that they mirror the rights outlined in the treaty. This means that Aboriginal rights unrelated to land and resources remain unmodified and enforceable as recognized by the common law, and those rights related to land and resources are modified only if required to reflect treaty rights. This new model cannot be viewed in isolation because it is a product of a long process stemming back to the origins of certainty in the historic treaties. This paper will therefore review the development of the partial modified rights approach in light of the traditional method of extinguishment, the alternate models of certainty, the critiques of such alternate models, and the demands for an outright recognition of rights. The divide between the divergent views held by the federal government and Indigenous peoples has not yet been bridged, although the certainty model in the EMRLCA presents the most recent stage in a process that appears to be gradually incorporating elements of recognition.

\section{Certainty and the Extinguishment of Aboriginal rights}

Aboriginal rights and treaty rights are related, but conceptually distinct, rights regimes. Aboriginal rights are based on the historical, cultural, and spiritual practices of Indigenous peoples and their use of the land prior to European contact. These rights, which existed prior to European contact, were recognized by the British Crown in the Royal Proclamation of 1763 and have been incorporated into the common law. ${ }^{3}$ In contrast, treaties are negotiated agreements between the Crown and Indigenous nations. The Royal Proclamation of 1763 ensured that treaties can only be executed between Indigenous peoples and the Crown - and not with private citizens - thus ensuring a nation-to-nation relationship. They comprise both the historic treaties, which were concluded from the early period of European contact to 1921, with the last numbered treaty, as well as the modern treaties comprising of land claims agreements and self-government agreements beginning with the 1975 James Bay and Northern Quebec Agreement (JBNQA). ${ }^{4}$ Aborig- inal rights are therefore considered 'inherent' and based on historic customs and practices, while treaties are based on a written negotiated agreement between Indigenous nations and the Crown. At the same time, however, Aboriginal rights and treaties are closely related on a more practical level because the negotiation of treaties often begins with the assertion of Aboriginal rights. ${ }^{5}$

For the federal government, certainty is achieved by treaties in at least three distinct ways. Firstly, treaties in their entirety provide certainty because of the resulting clarity over the ownership and use of lands and resources. Secondly, treaties contain provisions that release the government from all potential claims regarding Aboriginal rights originating prior to the treaty coming into force. Lastly, certainty is provided through provisions in the treaty which address the status of pre-existing Aboriginal rights. This paper is specifically concerned with the last of these three forms of certainty. These provisions explicitly seek to ensure that only treaty rights are enforceable, and that any pre-existing Aboriginal rights are effectively neutralized. Indigenous peoples reject this narrow and legalistic view that seeks to reduce treaties to real estate deals. For them, treaties form nation-to-nation relationships based on mutual respect and co-existence, and Aboriginal rights hold an important spiritual and cultural significance that form part of their identity. This is the core of the divergence between Indigenous peoples and the government on certainty, and the reason why various models have been developed in an effort to satisfy both parties. $^{6}$

\section{The First Certainty Model: “Cede, Release, and Surrender"}

Europeans and Indigenous nations concluded written treaties from at least the early $17^{\text {th }}$ century. The earliest of the historic treaties were non-aggression pacts which bear little resemblance to the latter historic treaties where land and rights were surrendered for specific benefits. In contrast, the treaties concluded between 1764 and 1862 focused on British acquisition and settlement on Indigenous lands, and they 
therefore began to include the extinguishment of Aboriginal title in exchange for annuities, reservations of land, and rights related to hunting and fishing in the ceded territory. This occurred under the Robinson Treaties of 1850, which provided for the partial extinguishment of title through a provision that holds that Indigenous peoples "cede, release, and surrender" rights to land. The post-Confederation numbered treaties concluded between 1871 and 1921 differed in detail from the Robinson treaties, although they contain the same core elements in that Indigenous peoples were to receive annuities and reservations in exchange for the surrender of their rights and title to the land. ${ }^{7}$ Importantly, the extinguishment of rights and title intensified with the numbered treaties. Under the terms of the Robinson treaties, reserved lands were set aside and not subject to surrender, while under the numbered treaties all Aboriginal title was surrendered, and it was left to the Crown to set apart reserves on the basis of the existing Indigenous population.

The majority of treaties in Canada were signed between 1800 and 1921. It is questionable whether full consent was received from Indigenous peoples for the extinguishment of their rights in the context of the historic treaties. Yet this problem arguably pales in comparison to what occurred after the 1920s, when the federal government abandoned treaty-making and turned to the use of the Indian Act and other forms of regulation that did not involve any consultation with Indigenous peoples before moving to assimilate them and extinguish their Aboriginal rights. ${ }^{8}$ This period culminated with the release of the federal government's White Paper on Indian Policy in 1969, which sought to end the special relationship between the federal government and Indigenous peoples through, among other measures, the termination of treaties. ${ }^{9}$

\section{“Cede, Release, and Surrender" in Modern Treaties}

The federal government abandoned the White Paper as a result of universal condemnation by Indigenous peoples. ${ }^{10}$ This step, along with the 1973 decision of Calder $v$ British Colum- bia (Attorney General), ${ }^{11}$ set the stage for a new process in the negotiation of treaties. In Calder, the Supreme Court of Canada found that the Nisga', with whom the federal government had never signed a treaty, continued to possess their Aboriginal rights to land following European settlement and the assumption of sovereignty by the British Crown. ${ }^{12}$ The Court was evenly split on the question of whether Nisga'a rights had been extinguished, but it definitively settled the issue of whether claims to rights and title by Indigenous peoples are enforceable in court, contrary to the White Paper. Resuming the treaty process therefore became necessary, and in that same year the federal government announced a new policy. ${ }^{13}$ A more detailed policy followed in 1981 which stressed finality with an exchange of rights and benefits for the extinguishment of Aboriginal title claims. ${ }^{14}$ It was under these policies that treaties began to be referred to as 'land claims', a term rejected by some Indigenous peoples because it implies that their rights have to be 'claimed,' and because it reduces treaty-making to real estate deals. ${ }^{15}$

Just as Indigenous peoples claim to have been misled when their rights were extinguished under the historical treaties, the Indigenous nations that negotiated treaties under the 1973 and 1981 policies assert that they agreed to the extinguishment of their rights under duress. The James Bay Cree of northern Quebec, for instance, commenced negotiations that resulted in the JBNQA as a result of Quebec's La Grande Hydroelectric in 1972, which included the damming of 10 rivers and the flooding of 25,000 square kilometers of Cree territory. ${ }^{16}$ The injunction which the Cree obtained from the Quebec Superior Court was promptly overturned by the Quebec Court of Appeal. ${ }^{17}$ The Cree believe that they were left with no choice other than to negotiate an agreement under the 1973 policy since the construction of the hydroelectric project would have been complete by the time their case reached the Supreme Court of Canada. ${ }^{18}$ The Cree were ultimately compelled to either negotiate an agreement that included the extinguishment of rights under the 1973 policy, or to face the prospect of their traditional homeland being flooded. 
The extinguishment of Aboriginal rights in the treaties negotiated under the 1973 and 1981 policies was accomplished through a "cede, release, and surrender" provision which was ironically much more widespread in scope than in the historic treaties because it applied to all Aboriginal rights, even those unrelated to land. For this reason, it is referred to as 'blanket extinguishment'. Consequently, the extinguishment of Cree rights was more widespread under the JBNQA than any other treaty, and this was further reiterated in the implementing legislation. ${ }^{19}$ The same approach was also applied in the Inuvialuit Final Agreement. ${ }^{20}$

The federal government acknowledged the discontent of Indigenous peoples with blanket extinguishment of rights in the 1983 Penner Report, which recommended that the policy be abolished. ${ }^{21}$ The report of the 1985 Federal Task Force to Review Comprehensive Land Claims, referred to as the Coolican Report, likewise made it clear that "blanket extinguishment of all aboriginal rights and title should no longer be an objective." 22 Two of the three alternatives to blanket extinguishment which were offered in the Coolican Report influenced government policy: only Aboriginal title would be extinguished, and not Aboriginal rights that are unrelated to land; Aboriginal title would only be surrendered to specific lands and preserved in the remainder. ${ }^{23}$

The federal government revised its comprehensive claims policy in 1986 by accepting the partial surrender of rights relating to title over blanket extinguishment. The two options offered to Indigenous groups under this policy were either the extinguishment of Aboriginal title in return for treaty rights, or alternatively, the surrender of Aboriginal title in non-reserved areas in return for defined treaty rights and the retention of Aboriginal rights in reserved areas. ${ }^{24} \mathrm{~A}$ surrender of all rights related to land and title was used in the Gwich'in Comprehensive Agreement, the Nunavut Land Claims Agreement, and the Sahtu Dene and Metis Comprehensive Land Claims Agreement, in exchange for specific rights under the agreement. ${ }^{25}$ This has been referred to as the 'surrender and grant back' model of certainty. ${ }^{26}$ Moreover, the term 'extinguishment' was not included in the legislation implementing the agreements, as was done with the JBNQA and the Inuvialuit Final Agreement.

The innovation of the 1986 policy was not applied fully until the 1993 Council for Yukon Indians Umbrella Final Agreement, which provides that the Yukon First Nations retain Aboriginal rights that are consistent with the terms of the treaty on the lands that they own and only surrender the rest. ${ }^{27}$ This partial extinguishment approach represented the most innovative model of certainty at that point in time, leading the Royal Commission on Aboriginal Peoples to declare that " $\mathrm{t}]$ he Yukon precedent currently stands alone among the modern treaties." 28 This model was used in that same year in four agreements which were negotiated under the Umbrella Agreement, ${ }^{29}$ and has since also been used in an additional seven. ${ }^{30}$ The partial surrender under this model comes with a backup release which extinguishes Aboriginal rights which may be found to conflict with the terms of the treaty. ${ }^{31}$

The federal government believed that the revised 1986 policy would resolve concerns with the previous two policies, although Indigenous peoples continued to oppose any preconditions in treaty negotiations that required even the partial extinguishment of rights. ${ }^{32}$ This concern was acknowledged at the international level, where the Human Rights Committee of the United Nations "recommended the practice of extinguishing inherent Aboriginal rights be abandoned as incompatible with article 1 of the International Covenant on Civil and Political Rights." ${ }^{33}$ At the same time, the federal government's willingness to move towards the partial extinguishment of Aboriginal rights was also viewed by the Royal Commission on Aboriginal Peoples as containing the seed for a new policy "that emphasizes reconciliation and co-existence between Aboriginal peoples and the Crown." ${ }^{34}$

\section{Alternate models of achieving certainty}

Several reports have recommended alternate models of achieving certainty that recognize Aboriginal rights. These include the 1995 special 
report of the Royal Commission on Aboriginal Peoples on certainty and extinguishment, and the 1995 report on certainty by A.C. Hamilton to the Minister of Indian and Northern Affairs. These reports agree in principle to achieving certainty while also recognizing Aboriginal rights, although their precise recommendations differ to some degree. Both reports stress that treaties should strive for clarity by fully outlining the rights of the parties to the extent possible. ${ }^{35}$

A number of the differences in the recommendations between the two reports were subtle and will not be summarized here, but there was one significant difference that needs to be considered. ${ }^{36}$ Hamilton suggested that certainty can be obtained by what he referred to as "assurances clauses", which would provide that Aboriginal rights would not be exercised in a manner that is inconsistent with the wording of the treaty. ${ }^{37}$ This would allow Aboriginal rights to be recognized and would provide certainty by ensuring that only the rights specified in the treaty can be exercised. The Royal Commission on Aboriginal Peoples, in contrast, recommended resolving any conflicts between a pre-existing Aboriginal right not enumerated in the treaty and a right held by the Crown or a third party contained in the treaty by allowing the latter to take precedence. ${ }^{38}$ These reports set the stage for the development of alternate approaches to certainty.

\section{Modification and Non-Assertion Models of Achieving Certainty}

The 1999 Nisga'a Final Agreement was the first treaty to contain an alternate model of achieving certainty because the Nisga'a refused wording that would result in the extinguishment of rights. ${ }^{39}$ Rather than extinguishing Aboriginal rights and replacing them with treaty rights, this model effectively took Aboriginal rights and modified them into the rights outlined in the treaty. ${ }^{40}$ Certainty is achieved for the federal government because this model prevents the Nisga'a from circumventing the negotiated settlement and asserting Aboriginal rights. At the same time, this model purports to maintain their spiritual, cultural, and historic connections to their rights because Aboriginal rights are not extinguished, and the enforceable rights under the treaty are a modified version of Aboriginal rights. As a result, the development of this model has been referred to as the Nisga'a Treaty's "single most important innovation." ${ }^{1}$

Despite the novelty of this approach to certainty, the modified Aboriginal rights approach has received its share of criticism. Firstly, the original version of this certainty model as found in the Nisga'a Final Agreement came with a back-up release. The release avoided the terminology of "cede, release, and surrender," but it was still designed to extinguish any pre-existing Aboriginal rights that escape modification and remain enforceable. ${ }^{42}$ The modified Aboriginal rights approach was used in a number of agreements since the Nisga'a Final Agreement. ${ }^{43}$ The backup release was not used in any of these agreements following the Nisga'a Final Agreement, and it is unlikely to be used again.

Even without the backup release, however, the modified Aboriginal rights approach remains open to criticism for its similarity to extinguishment for the simple fact that it ensures that the only rights that continue to exist are the specific ones outlined in the treaty. ${ }^{44}$ In theory, this model seeks to maintain the spiritual connection of Indigenous peoples to their rights, but in practice there is very little difference with surrender and grant back because the treaty rights are the only form of rights that continue to exist.

The second alternate model of achieving certainty appears at face value to correct the weakness with the modified Aboriginal rights approach: it allows for the continuation of Aboriginal rights alongside treaty rights, and the Indigenous nation agrees that it can only assert its treaty rights and not its pre-existing Aboriginal rights. This is referred to as the "nonassertion' model of certainty, and is found in the 2003 Tlicho Agreement and the 2006 Nunavik Inuit Land Claims Agreement (NILCA). The basic premise of this model is straightforward, and the certainty provision simply states that the Indigenous nation "will not exercise or assert any aboriginal or treaty right other than the rights set out in this Agreement." ${ }^{45}$ These agreements also contain a backup release where the Indigenous 
nation agrees to "cede, release, and surrender" any pre-existing Aboriginal rights that prevent them from exercising or enjoying their treaty rights, or which affect the ability of the federal government or third parties from exercising and enjoying their rights. ${ }^{46}$

The non-assertion model may appear to resolve the problems associated with the modified rights approach, yet it is tainted by an even more severe drawback in that it is based on a legal fiction that Aboriginal rights continue to exist. Both Aboriginal and treaty rights theoretically exist simultaneously, but only treaty rights are enforceable. Aboriginal rights in this model consequently defy the legal maxim $u b i$ jus $i b i$ remedium: where there is a right, there must be a remedy. The basis of this model may be that the non-assertable Aboriginal rights are held in abeyance and can be restored and exercised if the treaty ever ceases to operate. If this can occur, it would be a radical departure from the traditional view of treaties as binding not only the signatories but also the entire Indigenous nation and their descendants in perpetuity. ${ }^{47}$ Thus, whether this model in fact changes or affects the sui generis nature of treaties is something that requires further examination.

Aside from the most obvious limitation with non-assertion that Aboriginal rights remain in name only, this model also arguably fails to achieve what it set out to accomplish, namely, to allow Indigenous peoples to maintain their spiritual and cultural connection to their historic rights. This is simply not possible without such rights being enforceable. Unlike treaty rights, which can be identified with ease by referring to the text of the treaty, Aboriginal rights are discernible only in context and on a case-by-case basis by the courts. The courts were left with the task of defining Aboriginal rights in the context of specific cases because the constitutional conferences mandated by section 37 of the Constitution Act, 1982 were unsuccessful.

The federal government has grudgingly yielded to the demands of Indigenous people and has moved away from requiring the outright extinguishment of Aboriginal rights since the 1999 Nisga'a Final Agreement. The new models are still the target of criticism because Aboriginal rights as distinct from treaty rights simply do not exist in the modification model and, in the non-assertion model, they remain a hollow shell in name only. Accordingly, these models have been referred to as "nothing more than a matter of semantics." 48 Even the United Nations has been critical of these approaches. ${ }^{49}$ Nonetheless, these approaches represent important milestones in the quest for an approach to certainty that allows Indigenous peoples to preserve their historic rights.

\section{Achieving Certainty in the EMRLCA}

The EMRLCA, which came into force on February 15,2012 , is not a particularly controversial treaty because it covers a remote area with very limited third-party interests. Yet, it contains a unique model of achieving certainty which, thus far, incorporates the most from the calls for the recognition of Aboriginal rights.

The historic territory of the James Bay Cree is referred to as Eeyou Istchee, and it encompasses parts of northern Quebec as well as the islands and waters in James Bay and Hudson Bay which are part of Nunavut and known as the Eeyou Marine Region. The Cree live on the Quebec mainland, and the JBNQA settled their claims of rights and title in Quebec. The EMRLCA settles the Cree's rights and title in James Bay and Hudson Bay. These islands are uninhabited, but they have long been used by the Cree for their traditional practices, such as the annual goose hunt. The EMRLCA also covers an overlapping interest to the area with the Nunavik Inuit, including a jointly owned Cree and Inuit zone, which is addressed through a separate agreement reached by the two Indigenous groups and included as an appendix in both the EMRLCA and the NILCA..$^{50}$

The certainty model contained in the EMRLCA is a variant and an improved version of the modified rights approach to certainty. It contains the core elements of the modified rights approach found in the earlier agreements beginning with the Nisga'a Final Agreement, but it limits the modification to Aboriginal rights related to land and resources, and it only modi- 
fies those rights to the extent necessary to ensure that they are reflective of the rights as set out in the Agreement. There are, therefore, two distinct innovations to the modified rights approach in the EMRLCA when compared to previous uses of this model. Firstly, it only affects rights related to land and resources. ${ }^{51}$ Previous uses of the modified rights approach did not limit its effect to rights related to land and resources. The provision in the EMRLCA which releases government from all potential claims originating prior to the treaty coming into force, is likewise limited to rights related to land and resources, compared to earlier versions of the modified rights approach which contain a release of all claims related to Aboriginal rights. $^{52}$ The EMRLCA therefore directly affects Aboriginal rights related to land and resources only, and it leaves other potential rights intact under the common law.

The EMRLCA does not seek to enumerate the rights that the Cree may have, with the exception of those rights related to lands and resources. It does, however, explicitly refer to the right of self-government which the Cree may have without seeking to affect this right if it indeed exists. Presumably there was no pressing need to directly address the question of self-government in the EMRLCA because the islands in the Eeyou Marine Region are uninhabited. Nonetheless, the Agreement contains a long list of governance structures related to the establishment and management of protected areas, land use planning, and wildlife management. ${ }^{53}$ This innovation bears some resemblance to the third alternative to extinguishment offered by the Coolican Report, which was to leave aside differences related to the existence and content of Aboriginal rights and establish co-operative management regimes with neither party conceding its legal position. ${ }^{54}$ Accordingly, the possibility that the Cree may claim a right to self-government in relation to the islands in James Bay and Hudson Bay remains.

The second difference with the modified rights approach in the EMRLA compared to previous uses of this model is that the modification of rights related to lands and resources occurs only to the extent necessary to ensure that the rights are as reflected in the treaty. The relevant provisions are as follow:

Notwithstanding the common law, as a result of this Agreement and the ratification act, the aboriginal rights, including aboriginal title, of the Crees of Eeyou Istchee with respect to the use and ownership of lands and Resources, as they existed in Nunavut and the area comprising Hudson Bay and James Bay before the Effective Date of this Agreement, including their attributes, limitations and geographic extent, are

a) to the extent they are identical to the rights set out in this Agreement, including all their attributes, limitations and the geographic description of the rights set out in this Agreement, continued as aboriginal rights as set out in this Agreement, and

b) to the extent that they differ, from the rights set out in this Agreement, including all the attributes, limitations and geographic description of the rights set out in this Agreement, modified and continue only as set out in this Agreement.

For greater certainty, the aboriginal title of the Crees of Eeyou Istchee in Nunavut and the area comprising Hudson Bay and James Bay as it existed before the Effective Date of this Agreement is modified to the extent that it, including its attributes, limitations and geographic extent, differs from Cree title in Cree Lands as set out in this Agreement. ${ }^{55}$

This is a significant departure from the blanket modification that occurred under earlier uses of the modified rights approach. The rationale is that there is no reason to sever the historic ties if an Aboriginal right is identical to a treaty right. In this respect, the treaty serves to simply codify any unmodified rights related to land and resources. As a result of these two important departures from the modified rights approach, the certainty model in the EMRLCA can be referred to as the 'partial modified rights' approach.

The partial modified rights approach in the EMRLCA cannot completely escape critique, nor can it simply be equated with full recognition of Aboriginal rights. Partial modification is undoubtedly an improvement over complete 
modification, although it can still be subject to the same criticism that the modification of rights approach remains practically the same as the surrender and grant back variation of extinguishment. When Lisa Dufraimont refers to the use of the modified rights approach to allow the expansion of some rights and the contraction of others based on the interest of the parties, it should be expected that a contraction will occur more often than an expansion, particularly with respect to the territorial scope of land in the settlement. For instance, it has been estimated that the Nisga'a ultimately settled for approximately $10-25 \%$ of their traditional territory. ${ }^{56}$ The figure is likely much higher with respect to the Cree ownership of the islands in the Eeyou Marine Region because there are few third-party interests due to the remoteness of the area.

The second criticism that can be levelled against the certainty approach in the EMRLCA is that it makes very little practical difference whether a right is modified or whether it remains in its pre-existing form. The outcome of the EMRLCA is that it seeks to exhaustively detail Cree rights to lands and resources. If the general certainty provisions were not clear enough on this point, the agreement also provides that "[a]n unmodified aboriginal right of the Crees of Eeyou Istchee set out in this Agreement shall have the same legal status and effect as a modified right set out in this Agreement." ${ }^{\text {7 }}$ Moreover, even if it made any practical difference, there is no mechanism to determine whether a right is in its original pre-existing form or its modified form.

Despite these possible criticisms of the partial modified rights approach, this model meets the needs of the federal government and third parties for certainty while affecting pre-existing Aboriginal rights less than any other existing certainty model. It does so by recognizing the fact that the question of certainty for government and third parties typically arises with respect to the use and ownership of land and resources. This was first acknowledged by the federal government under the 1993 Council for Yukon Indians Umbrella Final Agreement. Continuing with this same principle in mind, blanket modification is likewise unnecessarily broad in scope when there could be a host of other Aboriginal rights unrelated to land and resources that do not need to be modified because they do not affect the interests of government and third parties.

It also makes sense at a theoretical level to allow Aboriginal rights to continue rather than to unnecessarily modify them. The Hamilton Report observed the need to clearly outline the rights that can be exercised by each party. While the partial modified rights approach leaves some uncertainty on whether an exercisable right is in its pre-existing or modified form, this does not conflict with Hamilton's recommendations since he said that "[i]t is not necessary to label the particular rights and responsibilities, only to agree to their existence and agree upon how they will be used in the future." ${ }^{58}$ Likewise, the Royal Commission on Aboriginal Peoples recommended " $[t]$ hat parties strive to identify, as exhaustively as possible, their respective rights by agreement." 59

Ultimately, however, controversy will likely follow this model of certainty, and changes will in all likelihood continue in small, incremental steps. A small, but symbolically important step which was not taken in the EMRLCA was the acknowledgement in the preamble that the Cree possess Aboriginal rights. Hamilton recommended a preamble in which the parties recognize and support each other's rights. ${ }^{60}$ Among the various proposed preambles which Hamilton lists includes one that reads: "[w]hereas the parties to this treaty agree that the (Aboriginal party) has Aboriginal rights in the Treaty Area." ${ }^{61}$ The preamble in the EMRLCA unfortunately continues the practice of merely outlining that the Cree "assert aboriginal rights and title to the Eeyou Marine Region." This is the exact type of preamble that Hamilton cautioned against because "the term 'assert' carries with it the implication that one part takes a certain position and other party does not agree with that position. These clauses start from a position of confrontation, indicating a lack of unanimity...." ${ }^{\prime 2}$ Given that the content of the EMRLCA clearly reveals that the parties were in agreement that the Cree possess Aboriginal rights and title in James Bay and 
Hudson Bay, as witnessed in the fact that a host of rights were left unmodified, it would not have been a large step for the preamble to outright declare that such rights exist. This may prove to be the logical next step.

\section{Conclusion}

After many years of protest by Indigenous peoples over the extinguishment of their rights, and two decades of attempting new models of achieving certainty that have been accused of merely being extinguishment in disguise, the certainty model in the EMRLCA appears to offer a modest degree of promise for the simple fact that it does the least amount of harm to Aboriginal rights of all the certainty models that exist to date. This new model may not fully satisfy the continuing demand for the outright recognition of Aboriginal rights, but it is certainly worthy of a broader discussion for the possibilities that it offers. At the very least, it reveals that the incorporation of an Indigenous perspective in treaty negotiations that counterbalances the government's quest for certainty and finality has been a gradual and evolutionary process. In reality, it remains unlikely that government will wholeheartedly adopt a full-fledged recognition approach to Aboriginal rights overnight, and it is far more likely that increased respect for Aboriginal rights will continue to come in the incremental steps taken thus far. These steps can continue to be taken because most Indigenous peoples still consider treaties as the preferred mechanism of defining their relationship with government. ${ }^{63}$ The partial modified rights approach in the EMRLCA can be considered an important step, but not the final step, in this process.

\section{Endnotes}

* Member of the Immigration and Refugee Board (IRB), Refugee Appeal Division (RAD). PhD Queen's, MA Carleton, LLB Ottawa, BSocSc Ottawa.

1 Being Schedule B to the Canada Act 1982 (UK), 1982, c 11.
2 For an account of the calls for recognition of Aboriginal rights, see especially Michael Asch and Norman Zlotkin, "Affirming Aboriginal Title: A New Basisfor ComprehensiveClaims Negotiations" in Michael Asch, ed, Aboriginal and Treaty Rights in Canada (Vancouver: UBC Press, 1997) 208 at 220; Jennifer Dalton, "Aboriginal Title and Selfgovernment in Canada: What is the True Scope of Comprehensive Land Claims Agreements?" (December, 2006) 22 Windsor Rev Legal SocIssues 29 at 31; Royal Commission on Aboriginal Peoples, Treaty Making in the Spirit of Co-existence: An Alternative to Extinguishment (Ottawa: Canada Communication Group, 1995) at 7; Rodolfo Stavenhagen, Report on the Situation of Human Rights and Fundamental Freedoms, on his Mission to Canada, ECOSOC, 61 $1^{\text {st }}$ Sess, UN Doc E/CN 4/2005/ 88/Add3 (2004) at 8.

3 Calder $v$ British Columbia (Attorney General), [1973] SCR 313, 34 DLR (3d) 145; Guerin $v$ The Queen, [1984] 2 SCR 335, 59 BCLR 301; $R v$ Sparrow, [1990] 1 SCR 1075, 46 BCLR (2d) 1.

4 James Bay and Northern Quebec Agreement (JBNQA). The federal enabling legislation is the James Bay and Northern Quebec Native Claims Settlement Act, SC 1976-77, c 32, and in Quebec An Act Approving the Agreement Concerning James Bay and Northern Quebec, C-67.

5 Robert Mainville, An Overview of Aboriginal and Treaty Rights and Compensation for their Breach (Saskatoon: Purich Publishing Inc., 2001) at 35.

6 The difference in views has been described as a "stark contrast". Dalton, "Aboriginal Title", supra note 2 at 71 .

7 Norman Zlotkin, "Post-Confederation Treaties" in Bradford Morse, ed, Aboriginal Peoples and the Law: Indian, Metis and Inuit Rights in Canada (Ottawa: Carleton University Press, 1985) 273 at 273-274.

8 Royal Commission on Aboriginal Peoples, Looking Forward, Looking Back, Vol 1 (Ottawa: Canada Communication Group, 1996) at 174-176

$9 \mathrm{Ibid}$ at 238. See also William Henderson and Derek Ground, "Survey of Aboriginal Land Claims" (1994) 26 Ottawa L Rev 187 at 212.

10 RCAP, Looking Forward, supra note 8 at 186; Henderson and Ground, "Survey", supra note 9 at 213.

11 Supra note 3.

12 Ibid.

13 Department of Indian Affairs and Northern Development, Statement of Claims of Indian and Inuit People (Ottawa: Queen's Printer, 1973). 
14 Minister of Indian Affairs and Northern Development, In All Fairness: A Native Claims Policy - Comprehensive Claims (Ottawa: DIAND, 1981) at 19; David Elliot, Law and Aboriginal Peoples in Canada, $3^{\text {rd }}$ ed (North York: Captus Press Inc., 1997) at 109.

15 Michael Coyle, "Addressing Aboriginal Land Rights in Ontario: An Analysis of Past Policies and Options for the Future - Part I" (2005) 31 Queen's LJ 75 at 78 (see especially footnote 2). See also John Borrows, "Domesticating Doctrines: Aboriginal Peoples after the Royal Commission” (2001) 46 McGill LJ 615; Gordon Christie, "Law Theory and Aboriginal Peoples” (2003) 2 Indigenous LJ 67.

16 Grand Council of the Crees (Eeyou Ischtchee) and the Cree Regional Authority, A Study in Contrast: A new Vision of Aboriginal Inclusion in Quebec and the Continuing Federal Government imposition of Extinguishment of Aboriginal Rights Across Canada (Submission of the Grand Council of the Cree (Eeyou Ischtee) to the Indigenous Rights in the Americas Project, Americas \& Caribbean Regional Experts Meeting, Georgetown, Guyana, June $\left.23^{\text {rd }}-25^{\text {th }}, 2003\right)$ at 8 .

17 James Bay Development Corporation et al., $v$ Kanatewat, [1975] CA 166 (QBCA); Kent Roach, "Aboriginal Peoples and the Law: Remedies for Violations of Aboriginal Rights" (1992) 21 Man LJ 498 at 502-04.

18 Grand Council, Study in Contrast, supra note 16 at 9.

19 JBNQA, supra note 4, art 2.1; James Bay and Northern Quebec Native Claims Settlement Act, supra note 4, s 3(3).

20 The Western Arctic Claim - The Inuvialuit Final Agreement, art 3(4); Western Arctic (Inuvialuit) Claims Settlement Act, SC 1984, c 24, s 3(2)(3).

21 House of Commons, Indian Self-Government in Canada: Report of the Special Committee (Ottawa: Queen's Printer, 1983) at 116, 147 [Penner Report].

22 Task Force to Review Comprehensive Claims Policy, Living Treaties, Lasting (Ottawa: Department of Indian Affairs and Northern Development, 1985) at 31 [Coolican Report].

23 Ibid at 41-42.

24 Department of Indian Affairs and Northern Development, Comprehensive Land Claims Policy (Ottawa: Supply and Services, 1986).

25 Gwich'in Comprehensive Land Claim Agreement, (1992), art 3.1.12. Nunavut Land Claims Agreement, (1993), art 2.7.1; Sahtu Dene and Metis Comprehensive Land Claims Agreement, (1994), art 3.1.11.
26 AC Hamilton, Canada and Aboriginal Peoples: A New Partnership (Ottawa: Minister of Public Work and Government Services Canada, 1995) at 24-25.

27 Umbrella Final Agreement between the Government of Canada, the Council for Yukon Indians and the Government of the Yukon, (1993), art 2.5.1.1.

28 RCAP, Treaty Making, supra note 2 at 42 . At the same time, the Umbrella Agreement was criticized by Hamilton for being "convoluted and very difficult to follow." See Hamilton, A New Partnership, supra note 26 at 88.

29 First Nation of Nacho Nyak Dun Final Agreement, (1993), art 2.5.1.1; Vunut Gwitchin First Nation Final Agreement, (1993), art 2.5.1.1; Champagne and Aishihik First Nations Final Agreement, (1993), art 2.5.1.1; Teslin Tlingit Council Final Agreement, (1993), art 2.5.1.1. All four were implemented through the Yukon First Nations Land Claims Settlement Act, SC 1994, c 34.

30 Little Salmon/Carmacks First Nation Final Agreement, (1997), art 2.5.1.1; Selkirk First Nation Final Agreement, (1997), art 2.5.1.1; Tronëk Hwëch'in Final Agreement, (1998), art 2.5.1.1; Tảan Kwachian Council Final Agreement, (2002), art 2.5.1.1; Kluane First Nation Final Agreement, (2003), art 2.5.1.1; Kwanlin Dun First Naiton Final Agreement, (2005), art 2.5.1.1; The Carcross/Tagish First Nation Final Agreement, (2005), art 2.5.1.1.

31 Yukon Umbrella Agreement, supra note 27, art 2.5.1.2. This provision is found in art 2.5.1.2 of all of agreements referenced in notes 28 and 29.

32 Dalton, "Aboriginal Title", supra note 2 at 52. See also Asch and Zlotkin, "Affirming", supra note 2 at 214-15.

33 Stavenhagen, Human Rights, supra note 2 at 7.

34 RCAP, Treaty Making, supra note 2 at 42.

35 Hamilton, A New Partnership, supra note 26 at 100.

36 Hamilton criticized the Royal Commission for its acceptance of partial extinguishment. Ibid at 71-72. See also Royal Commission on Aboriginal Peoples, Restructuring the Relationship, Vol 2 (Ottawa: Canada Communication Group, 1996) at 521.

37 Ibid at 101, 114.

38 RCAP, Treaty Making, supra note 2 at 71.

39 Douglas Sanders, "We Intend to Live Here Forever': A Primer on the Nisga'a Treaty" (1999) 33 UBC L Rev 103 at 127.

40 Nisga’a Final Agreement, (1999), arts 24-25.

41 Lisa Dufraimont, "Continuity and Modification of Aboriginal Rights in the Nisga'a Treaty" (2002) 35 UBC L Rev 455 at 483.

42 Nisga'a Final Agreement, supra note 40, art 26. 
43 Tsawwassen First Nation Final Agreement, (2007), arts 13-14; Tsawwassen First Nation Final Agreement Act, SC 2008, c 32; Maanulth First Nations Final Agreement, (2009), art 1.11.3; Maanulth First Nations Final Agreement Act, SC 2009, c 18; Yale First Nation Final Agreement, (2012), arts 2.4.3, 2.4.4; Tla'amin Final Agreement, (2014), art 42; Tla'amin Final Agreement Act, SC 2014, c 11. See also the Lheidli T'enneh Final Agreement, (2006), arts 39-40, which was narrowly rejected by the band members in a ratification vote.

44 Mary Hurley states that "some observers feel that essentially the same results flow from [the] modified rights approach". Mary Hurley, Settling Aboriginal Comprehensive Land Claims (Ottawa: Library of Parliament, 2009) at 9.

45 Land Claims and Self-government Agreement among the Tlicho and the Government of the Northwest Territories and the Government of Canada, (2003), art 2.6.1; Nunavut Inuit Land Claims Agreement, (2006), art 2.29.3 [NILCA].

46 Tlicho Agreement, ibid, arts 2.6.9, 2.6.10; NILCA, ibid, art 2.29.4.

47 Mainville, Overview, supra note 5 at 35.

48 Dalton, "Aboriginal Title", supra note 2. See also Paul Rynard, "Welcome In, but Check Your Rights at the Door': The James Bay and Nisga'a Agreements in Canada" (2000) 33 Can J Pol Sc 211 at 219.

49 Report of the Secretary General, Universal Realization of the Right of Peoples to Self-determination, GA, 61 ${ }^{\text {st }}$ Sess, UN doc A/61/333 (2006) at 3-4; Stavenhagen, Report, supra note 2 at 7.

50 Consolidated Agreement Relating to the Cree/ Inuit Offshore Overlapping Interest Area (Cree/
Inuit Offshore Overlap Agreement), found in the Eeyou Marine Region Land Claims Agreement, (2012), schedule 30-1 [EMRLCA]; NILCA, supra note 45 , schedule $28-1$.

51 EMRLCA, supra note 50, arts 2.23, 2.24.

$52 \mathrm{Ibid}$, art 2.30. The release provision in previous treaties using the modified rights model applied to all Aboriginal rights. See the Nisga'a Final Agreement, (1998), arts 26, 27; Tsawwassen First Nation Final Agreement, (2007), art 16; Maanulth First Nations Final Agreement, (2009), arts 1.11.6, 1.11.7; Yale First Nation Final Agreement, (2013), arts 2.4.6, 2.4.7; Lheidli Final T'enneh Agreement, (2018), art 42; Tla'amin Final Agreement, (2014), arts $46,47$.

53 EMRLCA, supra note 50, chapters 6, 8, 10 and 11.

54 Coolican Report, supra note 22 at 42. Hamilton considered this alternative and notes that the response from Indigenous peoples, governments, and third parties during his consultation process was "unenthusiastic." See Hamilton, A New Partnership, supra note 26 at 76

55 EMRLCA, supra note 50, arts 2.26, 2.27.

56 Dufraimont, "Continuity", supra note 41 at 491; Rynard, "Welcome In", supra note 48 at 225.

57 EMRLCA, supra note 50, art 2.29.

58 Hamilton, A New Partnership, supra note 26 at 101.

59 RCAP, Treaty Making, supra note 2 at 71.

60 Hamilton, A New Partnership, supra note 26 at 106.

61 Ibid at 105.

62 Ibid at 106.

63 RCAP, Restructuring the Relationship, supra note 36. 
